\title{
Adsorption Kinetics and Thermodynamics Study of Butylparaben on Activated Carbon Coconut Based
}

\author{
Patrick Atheba',2, N'Guadi Blaise Allou ${ }^{3 *}$, Patrick Drogui' ${ }^{1}$, Albert Trokourey ${ }^{2}$ \\ ${ }^{1}$ Institut National de la Recherche Scientifique (INRS-ETE), Université du Québec, Quebec City, Canada \\ ${ }^{2}$ Laboratoire de Chimie Physique, Université Félix Houphouët Boigny de Cocody-Abidjan, Abidjan, Côte d'Ivoire \\ ${ }^{3}$ Advanced Materials Group, Materials Science and Technology Division, CSIR-NEIST, Jorhat, India \\ Email: *allounguadi@yahoo.fr
}

How to cite this paper: Atheba, P., Allou, N.B., Drogui, P. and Trokourey, A. (2018) Adsorption Kinetics and Thermodynamics Study of Butylparaben on Activated Carbon Coconut Based. Journal of Encapsulation and Adsorption Sciences, 8, 39-57. https://doi.org/10.4236/jeas.2018.82003

Received: February 6, 2018

Accepted: May 28, 2018

Published: May 31, 2018

Copyright $\odot 2018$ by authors and Scientific Research Publishing Inc. This work is licensed under the Creative Commons Attribution International License (CC BY 4.0).

http://creativecommons.org/licenses/by/4.0/ (c) (i)

Open Access

\begin{abstract}
In this work, low cost coconut biochar based activated carbon (CBAC) was used for adsorption of Butylparaben (BPB) from aqueous medium. The prepared CBAC was characterized using BET, Boehm analysis and the adsorption equilibrium, kinetics and thermodynamics studies of $\mathrm{BPB}$ adsorption were carried out. During batch adsorption runs, the effects of factors, such as contact time (0 - $300 \mathrm{~min}), \mathrm{CBAC}$ dose $(200-800 \mathrm{mg}), \mathrm{pH}(3-11)$ and solution temperatures $(303-348 \mathrm{~K})$ were investigated on BPB removal. Experimental results reveal that the BPB removal efficiency on CBAC is higher than $97 \%$ under acidic and neutral conditions. Equilibrium data were fitted by Langmuir, Freundlich and Temkin isotherm models with correlation coefficient more than 0.9. The pseudo-second order kinetic model was observed to fit well the adsorption data. Thermodynamic analysis shows positive values of standard Gibb's free energy, suggesting the non-spontaneity of the process. The changes in enthalpy $\left(0.2 \mathrm{~J} \cdot \mathrm{mol}^{-1}\right)$ and entropy $\left(19 \mathrm{~J} \cdot \mathrm{mol}^{-1}\right)$ were found to be endothermic with an increase of randomness. The high adsorption efficiency of the synthesized coconut biochar materials with low cost indicates that it may be a promising adsorbent for removing organic compounds.
\end{abstract}

\section{Keywords}

Coconut Shell, Activated Carbon, Adsorption, Butylparaben, Kinetics, Isotherm

\section{Introduction}

During these last 20 years, concerns about the consequences of human and wild- 
life to long term exposure to substances in the environment that can interact with the endocrine system, are increasingly criticized. These substances, leading to biological perturbations, are commonly referred to "endocrine disruptors". According to the WHO definition, endocrine disruptors are natural or artificial chemical substances foreign to the body that can interfere with the operating systems and induce endocrine resulting in deleterious effects on the body or on his descendants [1].

Several studies have shown the potential and actual harmful effects of these compounds on wildlife and humans [2] [3] [4] [5]. Among these compounds, parabens, which are antimicrobial, antifungal and antioxidant agents, are widely used in the food, cosmetic and pharmaceutical industries [6]. Their presence in the aquatic environments at different concentrations is ranging from $\mathrm{ng} \cdot \mathrm{L}^{-1}$ to $\mu \mathrm{g} \cdot \mathrm{L}^{-1}$ [7]. Recently, the estrogenic effects of parabens, in particular Propylparaben and Butylparaben (BPB), affecting adversely the secretion of testosterone and the male reproductive system function in rats and mice, were demonstrated [2] [3] [4] [5] [8]. Furthermore, studies have shown that some parabens exhibit toxicity on testicular mitochondria at low concentration [9]. Gomez et al. [10] indicated that the main source of parabens in the aquatic environment remains wastewater treatment plant. Therefore, the removal of endocrine disruptors from waste water is an urgent need to preserve the environment and aquatic life. Several research teams are focusing their research to remove or degradate these compounds through various physical and chemical techniques, such as photocatalysis [11], sonolysis [12], photosonolysis [13], adsorption [14], nanofiltration [15] or reverse osmosis [16], with satisfactory results. Very few reports are there about the removal of BPB using photodegration, photosonolysis and adsorption. Among these methods, adsorption is more efficient than other methods in the removal of organic compound from waste water. One of the great advantages of activated carbon is their large surface area and large porous volumes to adsorb high quantity of pollutant. Many researchers have shown great interest in the development of low cost adsorbent prepared from agricultural waste [17] [18]. In addition to their low cost, activated carbon prepared from agricultural waste bioproducts, allows limiting waste stocks and transforming waste into more valuable products with an added value. Since activated carbons possess large surface area, porosity and surface chemistry, these properties give them great adsorption ability for the uptake of organics compounds.

The objective of the present work is to prepare biochar based activated carbon from coconut shells of Côte d'Ivoire (West Africa), which are rejected by the farmers as waste materials [19] and to evaluate its use as adsorbent material for adsorption of BPB from aqueous solution in batch process. Adsorption kinetics, isotherms models and thermodynamics parameters of BPB on the synthesized biochar were investigated. 


\section{Materials and Methods}

\subsection{Materials}

Butyl parahydroxybenzoate (BPB) (purity $>99 \%$ ) was obtained from an analytical grade reagent, Sigma Aldrich, US. The physico-chemical properties and molecular structure of BPB are summarized in Table 1 and Figure 1, respectively. Fisher Scientific supplied $\mathrm{NaOH}$ and $\mathrm{H}_{2} \mathrm{SO}_{4}$. All the chemicals and reagents used in this study were of analytical grade and used as received. All the solutions and reagents were prepared with deionized water.

\subsection{Synthesis of Coconut Biochar Based Activated Carbon and Characterization}

The adsorbent used in this study was prepared from coconut shell biochar. The experimental conditions and activated carbon characteristics were described by Atheba [20]. Briefly, a barn containing the coconut shells and fire embers is kept in a closed enclosure protected from oxygen. The heat exchanges inside the barrel will transform the coconut shells into inactive carbon, this is the carbonization process. Since the carbonization of the coconut shell was done on an artisanal basis, parameters such as temperature and atmosphere were not determined. The obtained carbon is crushed and sieved until carbon grains with a diameter of between 1 and $2 \mathrm{~mm}$ are obtained followed by its physical activation in a thermo-programmable furnace. Table 2 summarizes the furnace parameters.

The Brunauer-Emmett-Teller (BET) specific surface area and Barrett-Joyner-Halenda (BJH) pore size of the sample were measured by adsorption of nitrogen liquid at $77 \mathrm{~K}$ collected from a Micromeritics Tristar 3000 surface area and pore size analyzer. The surface functional groups were determined according to the method of Boehm [21]. This method consists in the neutralization of the various oxygenated groups. Therefore, the carboxylic, lactone

Table 1. Physico-chemical properties of BPB.

\begin{tabular}{cc}
\hline Parameter & Value \\
\hline Molecular Formula & $\mathrm{C}_{11} \mathrm{H}_{14} \mathrm{O}_{3}$ \\
Molecular Weight $\left(\mathrm{g} \cdot \mathrm{mol}^{-1}\right)$ & 194.23 \\
Solubility in water $\left(\mathrm{mg} \cdot \mathrm{L}^{-1}\right)$ & 158 \\
Absorption Maxima $(\mathrm{nm})$ & 255 \\
\hline
\end{tabular}<smiles>CCCCOC(=O)c1ccc(O)cc1</smiles>

Figure 1. Butylparaben molecular structure. 
Table 2. Parameters for carbon activation.

\begin{tabular}{ccccc}
\hline \multicolumn{5}{c}{ Activation parameters } \\
\hline Time & Atmosphere & Flow rate & Temperature & Heating rate \\
\hline $3 \mathrm{~h}$ & $\mathrm{~N}_{2}+\mathrm{CO}_{2}$ & $100 \mathrm{ml} \cdot \mathrm{min}^{-1}$ & From $20^{\circ} \mathrm{C}$ to $800^{\circ} \mathrm{C}$ & $20^{\circ} \mathrm{C} \mathrm{min}^{-1}$ \\
\hline
\end{tabular}

and phenol functions were dosed with increasing force bases $\left(\mathrm{NaHCO}_{3}, \mathrm{Na}_{2} \mathrm{CO}_{3}\right.$, $\mathrm{NaOH}$ ) while the total basicity was determined with hydrochloric acid.

\subsection{Batch Mode Adsorption}

The ability of activated carbon to uptake BPB from aqueous solution was evaluated in batch mode adsorption. BPB stock solution of $100 \mathrm{mg} \cdot \mathrm{L}^{-1}$ was prepared by dissolving the appropriate amount of BPB in $1000 \mathrm{ml}$ of volumetric flask and completing the volume with deionized water up to mark. The experimental solutions of the desired concentration were obtained by successive dilutions.

The first set of tests consisted to determine equilibrium time of adsorption. For this purpose, 3 erlenmeyer flasks containing $200 \mathrm{ml}$ of $10 \mathrm{mg} \cdot \mathrm{L}^{-1} \mathrm{BPB}$ and activated carbon $\left(4 \mathrm{~g} \cdot \mathrm{L}^{-1}\right)$ were shaken at $150 \mathrm{rpm}$, rom temperature $\left(25^{\circ} \mathrm{C} \pm\right.$ $2^{\circ} \mathrm{C}$ ), during 300 min expected to reach equilibrium and the measured $\mathrm{pH}$ was $7.0 \pm 0.5$. At the regular interval time $(0,5,15,30,60,120,180$ and $300 \mathrm{~min})$ samples were withdrawn and the amount of $\mathrm{BPB}$ adsorbed was determined by measuring the residual $\mathrm{BPB}$ concentration in the liquid phase using an OMEGA-UV-Vis (Thermoscientifique, France) spectrophotometer calibrated at the wavelength of $255 \mathrm{~nm}$.

The effect of activated carbon dose on BPB adsorption process was conducted at fixed $\mathrm{pH}(\mathrm{pH} 7 \pm 0.5)$ and fixed initial BPB concentration $\left(10 \mathrm{mg} \cdot \mathrm{L}^{-1}\right)$ in 200 $\mathrm{ml}$ of solution. Different activated carbon masses were used $\left(1,2,3\right.$ and $\left.4 \mathrm{~g} \cdot \mathrm{L}^{-1}\right)$. The flasks were shaken at $150 \mathrm{rpm}$ for $180 \mathrm{~min}$ (according the equilibrium time determined above) and samples were collected for analysis.

The next set of tests was performed to determine the effects of $\mathrm{pH}$ on adsorption process. Adsorption was studied at $\mathrm{pH} 3,5,7,9$ and 11 at $25^{\circ} \mathrm{C} \pm 2^{\circ} \mathrm{C}$, in 10 $\mathrm{mg} \cdot \mathrm{L}^{-1}$ of initial BPB concentration, $200 \mathrm{ml}$ of solution and $4 \mathrm{~g} \cdot \mathrm{L}^{-1}$ of activated carbon. The solution initial $\mathrm{pH}$ value solution was adjusted using $0.1 \mathrm{M} \mathrm{H}_{2} \mathrm{SO}_{4}$ and $0.1 \mathrm{M} \mathrm{NaOH}$, solutions. The flasks were shaken at $150 \mathrm{rpm}$ for $180 \mathrm{~min}$, and samples were collected for analysis.

The adsorption isotherms experiments were carried out using different initial concentrations of $\operatorname{BPB}\left(5,10,15,20,25,30,40,50 \mathrm{mg} \cdot \mathrm{L}^{-1}\right)$ and the same dose of activated carbon $\left(4 \mathrm{~g} \cdot \mathrm{L}^{-1}\right)$. The mass of activated carbon was fixed according to the result obtained during the effect of activated carbon dose on BPB adsorption process. The flasks were shaken at $150 \mathrm{rpm}$ for $180 \mathrm{~min}$ and samples were taken for analysis. Room temperature and optimum $\mathrm{pH}$ were used for test.

The adsorption kinetic experiments were carried out using $200 \mathrm{ml}$ of $10 \mathrm{mg}$ $\mathrm{L}^{-1}$ of BPB solution and at a fixed concentration of activated carbon $\left(4 \mathrm{~g} \cdot \mathrm{L}^{-1}\right)$. The flasks were shaken at $150 \mathrm{rpm}, 25^{\circ} \mathrm{C} \pm 2^{\circ} \mathrm{C}$, and $\mathrm{pH} 7.0 \pm 0.5$. Samples were 
withdrawn at regular interval times and analyzed.

The last set of analysis was consisted to evaluate the thermodynamic parameters such as Gibbs free energy $\left(\Delta G^{\circ}\right)$, enthalpy $\left(\Delta H^{\circ}\right)$ and entropy $\left(\Delta S^{\circ}\right)$ changes, to understand the feasibility and nature of the adsorption process. For this, erlenmeyer flasks containing $200 \mathrm{ml}$ of solution at $10 \mathrm{mg} \cdot \mathrm{L}^{-1}$ of $\mathrm{BPB}$ and $4 \mathrm{~g} \cdot \mathrm{L}^{-1}$ of activated carbon were shacking at $150 \mathrm{rpm}$ and different temperatures $\left(10^{\circ} \mathrm{C}\right.$, $22^{\circ} \mathrm{C}, 30^{\circ} \mathrm{C}, 40^{\circ} \mathrm{C}$ ) during $180 \mathrm{~min}$.

The percentage of BPB removal is calculated using the following equation:

$$
\text { Percentage Removal }(\mathrm{PR} \%)=100 \times\left(C_{i}-C_{f}\right) / C_{i}
$$

The amount adsorbed in $\left(\mathrm{mg} \cdot \mathrm{g}^{-1}\right)$ is calculated using Equation (2):

$$
q_{e}=\left(C_{i}-C_{f}\right) \times V / m
$$

where $C_{i}$ and $C_{f}$ are the initial and final concentrations $\left(\mathrm{mg} \cdot \mathrm{L}^{-1}\right)$ of BPB in liquid phase, respectively; $V(\mathrm{~L})$ represents the volume of solution and $m(\mathrm{~g})$ the mass of activated carbon.

\section{Results and discussion}

\subsection{Characterization of the Adsorbent}

The most used materials in adsorption process are activated carbons. This is because of their high adsorption capacity, high surface area, micro porous structure, high degree of surface and high chemical and mechanical stability [22]. Therefore, $\mathrm{N}_{2}$ adsorption isotherm was measured to determine the surface area and pore size of the adsorbent. The surface area was determined by a fitting analysis based on the BET equation. The quantitative assessment of the acido-basic functions of the surface was obtained by Boehm titration. According to the IUPAC classification of absorption isothermal curves, the $\mathrm{N}_{2}$-sorption (Figure 2) would be of type I, indicating the presence of micropores with an average pore size of $\approx 2.36 \mathrm{~nm}$. The as prepared AC possesses a high surface area up to $443.13 \mathrm{~m}^{2} \cdot \mathrm{g}^{-1}$ with a pore volume of $\approx 0.22 \mathrm{~cm}^{3} \cdot \mathrm{g}^{-1}$. Table 3 gives the

\begin{tabular}{|c|c|c|c|}
\hline \multirow{3}{*}{ Physical } & \multicolumn{2}{|c|}{$\mathrm{S}_{\mathrm{BET}}\left(\mathrm{m}^{2} \cdot \mathrm{g}^{-1}\right)$} & 443.134 \\
\hline & \multicolumn{2}{|c|}{ Pore volume $\left(\mathrm{cm}^{3} \cdot \mathrm{g}^{-1}\right)$} & 0.220 \\
\hline & \multicolumn{2}{|c|}{ Pore size $(\AA ̊)$} & 23.619 \\
\hline \multirow{5}{*}{ Chemical } & & $-\mathrm{OH}$ & 0.172 \\
\hline & Acid (meq.g $\left.{ }^{-1}\right)$ & -COO- & 1.038 \\
\hline & & $-\mathrm{COOH}$ & 2.780 \\
\hline & \multicolumn{2}{|c|}{ Base $\left(\mathrm{meq} \cdot \mathrm{g}^{-1}\right)$} & 1.075 \\
\hline & \multicolumn{2}{|c|}{$\mathrm{pH}$} & 10.2 \\
\hline \multirow{2}{*}{ Structure } & \multicolumn{2}{|c|}{ Grain size (mm) } & $1<\phi<2$ \\
\hline & \multicolumn{2}{|c|}{ Appearance } & Spangle \\
\hline
\end{tabular}

Table 3. Structural and physico-chemical features of the adsorbent. 


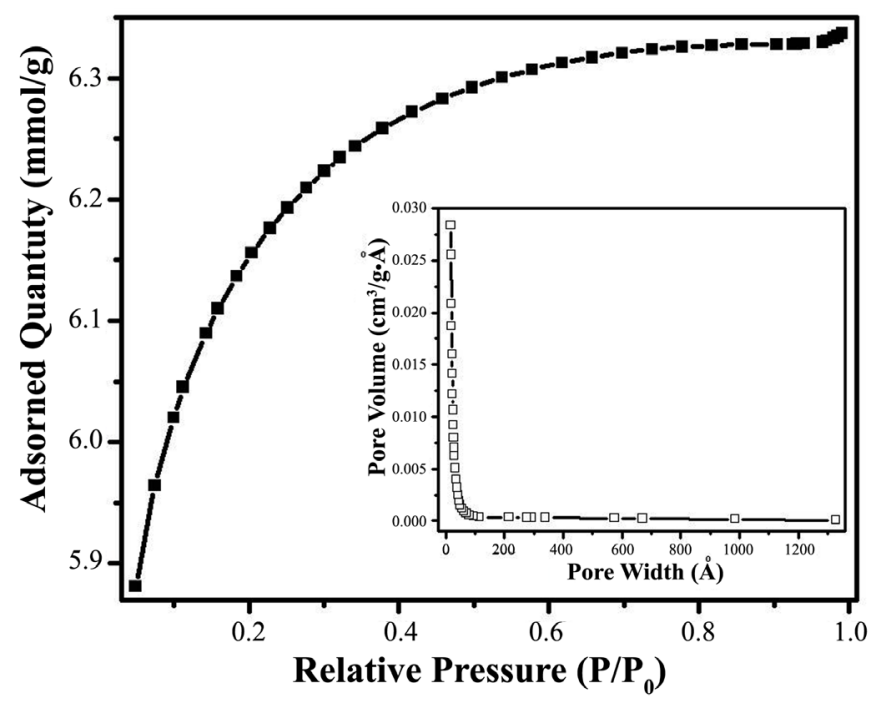

Figure 2. Adsorption isotherm of $\mathrm{N}_{2}$ at $77 \mathrm{~K}$ on $\mathrm{AC}$ and pore size distribution (inset) of AC.

structural and physico-chemical properties of the prepared adsorbent. It is interesting to note that the activated carbon is more acid, but has also some basic functions.

\subsection{BPB Removal by Coconut Shell Biochar}

\subsubsection{Effect of Contact Time}

The impact of contact time on the adsorption capacity of activated carbon (AC) for $\mathrm{BPB}$ removal was evaluated. In Figure 3 , it clearly depicts that, the removal of BPB by AC increases as the contact time increases. The removal of BPB occurred in two main phases. The sorption of $\mathrm{BPB}$ is fast during the first 60 minutes, where about $85.2 \%$ of the initial concentration of BPB were removed; then slows down around $3 \mathrm{~h}$, until the end of the run. The equilibrium is achieved almost in $3 \mathrm{~h}$. At this time, the adsorption efficiency was $97.4 \%$. A contact time of $3 \mathrm{~h}$ was thus established for the following runs. The fast adsorption could be due to the high availability of free active sites at the beginning of adsorption process, whereas after a specific period of time, actives sites will be gradually occupied which will make the process of adsorption slower [23]. Similar results have been highlighted in the literature on the removal of dye [14] [24].

\subsubsection{Effect of Adsorbent Dosage}

The effect of activated carbon dose on BPB ( $\mathrm{pH} 7$ and $10 \mathrm{mg} \cdot \mathrm{L}^{-1}$ ) removal was studied and the result obtained is depicted in Figure 4. It is observed that the adsorption efficiency of BPB by activated carbon increases with an increase in concentration of sorbent. The adsorption efficiency increases from $41 \%$ to $95 \%$ with increasing the adsorbent dose from 1 to $4 \mathrm{~g} \cdot \mathrm{L}^{-1}$. This may be due to an increase in the availability of surface active centers. The same observation is also reported in literature [25] [26]. A contact time of $3 \mathrm{~h}$ and the dosage of activated 


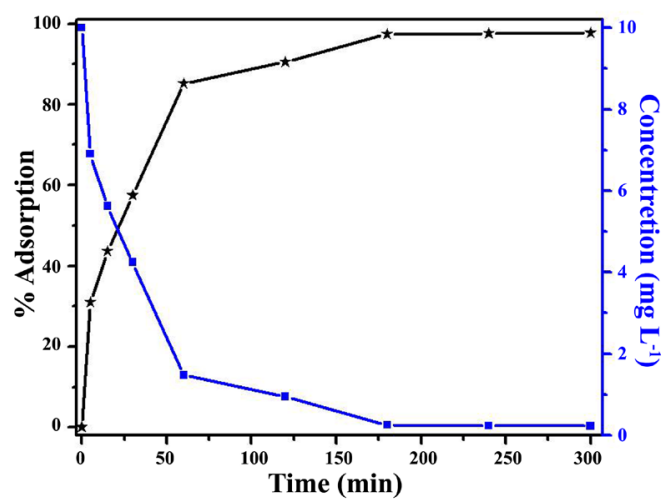

Figure 3. Effect of contact time on the uptake of BPB by AC.

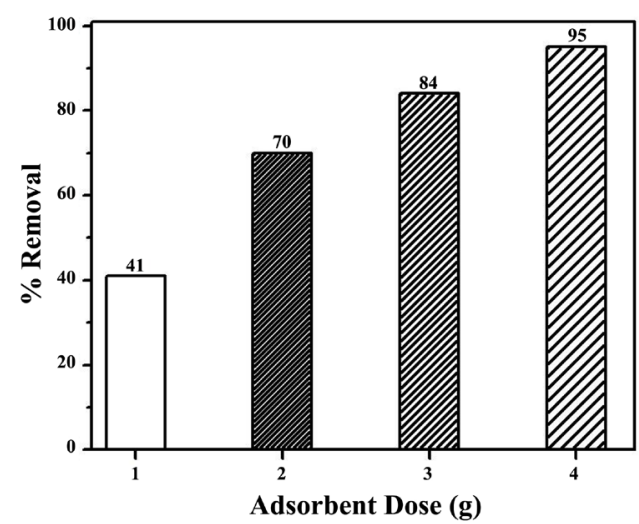

Figure 4. Effect of adsorbent dose on the BPB removal from aqueous solutions by AC.

carbon of $4 \mathrm{~g} \cdot \mathrm{L}^{-1}$, were thus considered for the following runs.

\subsubsection{Effect of pH on BPB Removal}

The influence of the initial aqueous solution $\mathrm{pH}$ value is an important parameter that affects the adsorption process [11]. The study of BPB adsorption on activated carbon coconut shell-based is carried out during $3 \mathrm{~h}$, at different $\mathrm{pH}$ values $(3-11)$ of $10 \mathrm{mg} \cdot \mathrm{L}^{-1} \mathrm{BPB}$ solution. This $\mathrm{pH}$ range (Figure 5) allows to investigate the evolution of $\mathrm{BPB}$ in two chemical forms due to its pKa 8.24 [3]. At $\mathrm{pH}<\mathrm{pKa}, \mathrm{BPB}$ existed as a neutral molecule, while it mainly existed as a negative species when $\mathrm{pH}$ value was higher than $\mathrm{pKa}$.

Figure 6 shows the initial $\mathrm{pH}$ effect of BPB adsorption by AC. The maximum percentage of $\mathrm{BPB}$ uptake (97.87\%), occurs at $\mathrm{pH} 3$. However, increasing $\mathrm{pH}$ to 11 , the adsorption capacity decreases to $82.51 \%$. As the $\mathrm{pH}$ of the system increases, the number of negatively charged binding sites would increase. Therefore, at low $\mathrm{pH}$ range, the surfaces of activated carbon might become positively charged due to the excess of $\mathrm{H}^{+}$ion in solution. The electrostatic attraction between BPB molecule and the adsorbent surface increase the amount of $\mathrm{BPB}$ adsorbed. At the high $\mathrm{pH}$ range, the surface of activated carbon might become negatively charged due to excess of $\mathrm{OH}^{-}$ions concentration, which will compete with BPB for the available positively charged sites on the adsorbent 


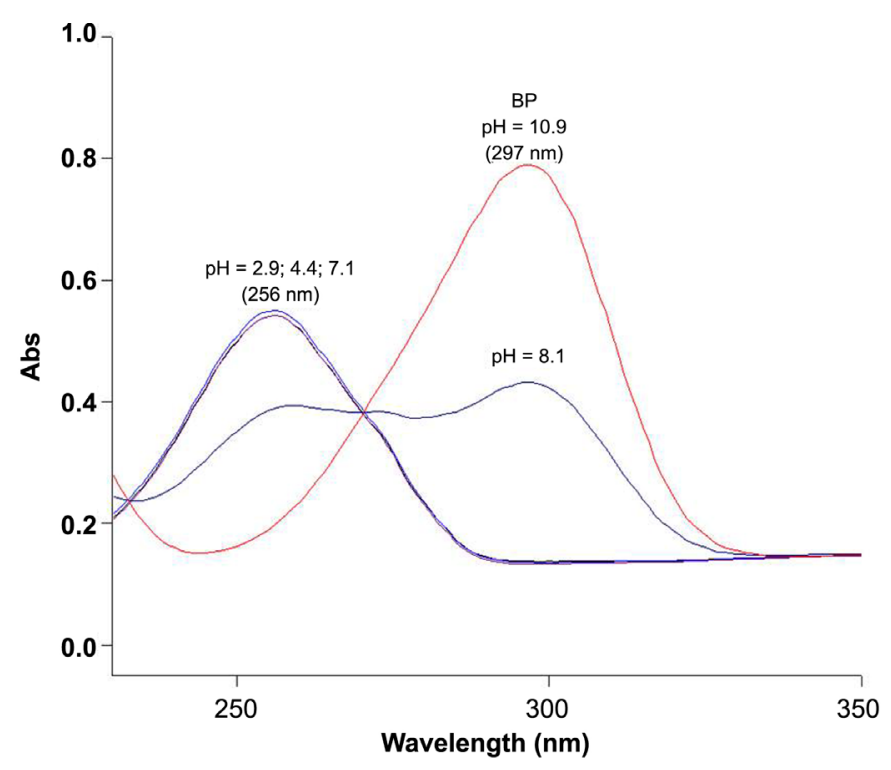

Figure 5. BPB species versus $\mathrm{pH}$.

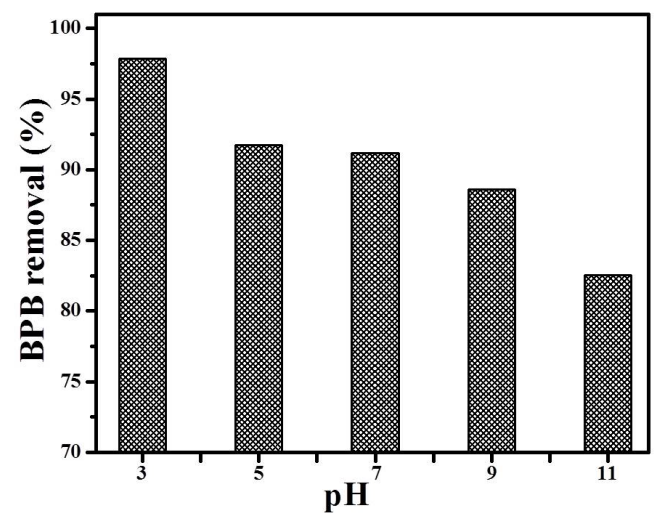

Figure 6. Effect of initial $\mathrm{pH}$ solution on the BPB adsorption from aqueous solutions by AC.

surface, thus decreasing the removal efficiency of BPB. Figure 5 shows in addition that, at $\mathrm{pH}>\mathrm{pKa}, \mathrm{BPB}$ is in its deprotonated ionic (maximum wavelength is $297 \mathrm{~nm}$ ) form due to the ionization of the hydroxyl group, increasing its hydropholicity. In these conditions, the adsorption process was governed by physical phenomenon. The high removal value $(85.51 \%)$ was mainly due to the BPB ionization, that gave an ionic form with different wavelength $(297 \mathrm{~nm})$.

Some authors [27] [28] assumed that the presence of functional groups on the adsorbent surface influences the adsorption ability. The activated carbon efficiency could be depend on several mechanisms in the removal of the BPB. In this study, the adsoprtion process versus $\mathrm{pH}$ shows that ion-exchange, electrostatic interactions, capillarity and BPB ionization form are involved in the removal mechanism. Similar phenomena were observed in the work reported by Hawari et al. [29]. 


\subsubsection{Adsorption Isotherm Studies}

The equilibrium adsorption isotherms are important in the development of adsorption process. Adsorption characteristics of an adsorbent are used to estimate the adsorbent/adsorbate interaction. In this study, four isotherm models were used to investigate and elucidate the adsorption behavior of BPB onto activated carbon. Data obtained from the experiments were fitted by Langmuir, Freundlich, Temkin and Dubinin-Radushkevich isotherm models.

1) Langmuir isotherm

The Langmuir isotherm model was chosen for the estimation of maximum adsorption capacity corresponding to complete monolayer coverage on the biomass surface [30]. The linearized form of the Langmuir isotherm is described by the following equation:

$$
1 / Q_{e}=1 / Q_{m} K_{L} C_{R}+1 / Q_{m}
$$

where, $Q_{e}$ is the amount of BPB adsorbed per mass of adsorbent $\left(\mathrm{mg} \cdot \mathrm{g}^{-1}\right), C_{r}$ is the residual concentration of $\mathrm{BPB}, Q_{m}$ is the monolayer adsorption capacity (mg.g ${ }^{-1}$ ) and $K_{L}$ is the Langmuir constant. The isotherm parameters, $Q_{m} K_{L}$ and the coefficient of correlation are presented in Table 4 . The sorption capacity, $Q_{m}$, which is a measure of the maximum sorption capacity corresponding to the complete monolayer coverage showed that the activated carbon adsorption capacity for BPB was $7.519 \mathrm{mg} \cdot \mathrm{g}^{-1}$. The adsorption coefficient, $K_{L}$, related to the apparent energy of sorption is $0.093 \mathrm{~L} \cdot \mathrm{mg}^{-1}$ and the correlation coefficient 0.979 . This observation showed that the energy of adsorption is not very favorable to $\mathrm{BPB}$, probably due to its weak interaction between $\mathrm{BPB}$ molecules and the activated carbon surface properties. The same capacity order was reported [28] for organic compounds sorption on coconut shell activated carbon. According to the Langmuir model this could suggest some homogeneity in the surface or pores of the activated carbon [31].

The essential factor $K_{L}$ is used to evaluate the feasibility of the adsorption process as favorably and nature of the isotherm.

$$
R_{L}=1 /\left(1+K_{L} C_{i}\right)
$$

where $K_{L}$ is the Langmuir constant and $C_{i}$ is the initial concentration of BPB.

The $R_{L}$ value for BPB adsorption on activated carbon is $0.64\left(0<R_{L}<1\right)$, indicating that the adsorption process is favorable [32].

2) Freundlich isotherm

The Freundlich model was chosen to estimate the adsorption intensity of the adsorbate on the adsorbent surface. The linearized form of the Freundlich isotherm is given by:

$$
\ln Q_{e}=\ln \ln K_{F}+\ln C_{e} \times 1 / n
$$

where $K_{F}$ is the Freundlich isotherm constant related to the adsorption capacity, whereas $n$ describes the adsorption intensity [33]. Table 4 shows that the adsorption data for activated carbon were found to fit with Freundlich model having a correlation coefficient of 0.973 . The Freundlich adsorption equation assumes that a multi-layer adsorption could occur on the surface of the 
Table 4. Adsorption isotherm parameters for the removal of BPB by activated carbon.

\begin{tabular}{cccccc}
\hline \multicolumn{5}{c}{ Isotherm } \\
\hline & Langmuir & \multicolumn{3}{c}{ Freundlich } \\
\hline$Q\left(\mathrm{mg} \cdot \mathrm{g}^{-1}\right)$ & $K_{L}\left(\mathrm{~L} \cdot \mathrm{mg}^{-1}\right)$ & $R^{2}$ & $K_{F}\left(\mathrm{mg} \cdot \mathrm{g}^{-1}\right)$ & $n$ & $R^{2}$ \\
7.52 & 0.093 & 0.979 & 0.773 & 1.553 & 0.973 \\
& Temkin & & & Dubinin-Radushkevich & \\
$b_{T}\left(\mathrm{~kJ} \cdot \mathrm{mol}^{-1}\right)$ & $K_{T}\left(\mathrm{~L} \cdot \mathrm{mg}^{-1}\right)$ & $R^{2}$ & $Q_{m}\left(\mathrm{mg}^{-1}\right)$ & $K_{D-R}\left(\mathrm{~mol} \cdot \mathrm{kJ}^{-1}\right)^{2}$ & $R^{2}$ \\
24.49 & 0.874 & 0.909 & 0.390 & 2.681 & 0.785 \\
\hline
\end{tabular}

adsorbent [26]. The value of $n$ obtained $(n>1)$ indicates that BPB is adsorbed on the activated carbon. This observation seems to explain the co-adsorption phenomenon due to the attraction generated by the BPB molecule after recovery the activated carbon surface, creating a multi-layer. Djilani et al. [34] reported similar results, when they studied the removal of methyl orange and methylene blue using activated carbon prepared from apricot stones and commercial activated carbon.

3) Temkin isotherm

The Temkin isotherm [35] reflects the fact that the heat of adsorption of all the molecules of the cover layer decreases linearly with the recovery due to the decrease of adsorbent/adsorbate interactions. The linearized form of Temkin isotherm is expressed by:

$$
Q_{e}=R T \ln K_{T} \times 1 / b_{T}+R T \ln C_{e} \times 1 / b_{T}
$$

where, $b_{T}$ is the Temkin constant related to the heat of adsorption $\left(\mathrm{J} \mathrm{mol}^{-1}\right), K_{T}$ is the equilibrium binding constant $\left(\mathrm{L} \mathrm{g} \mathrm{g}^{-1}\right), R$ the gas constant $\left(8.314 \mathrm{~J} \mathrm{~mol}^{-1} \cdot \mathrm{K}^{-1}\right)$, $T$ is the absolute temperature (K), $Q_{e}$ is the amount of BPB adsorbed per mass of adsorbent $\left(\mathrm{mg} \cdot \mathrm{g}^{-1}\right)$ and $C_{e}$ is the residual concentration of BPB at the equilibrium. The values of the parameters are given in Table 4 . The correlation coefficient $\left(\mathrm{R}^{2}=0.909\right)$ indicates that Temkin's model fits the BPB adsorption on the activated carbon. The constant of Temkin $K_{T}\left(0.317 \mathrm{mg} \cdot \mathrm{g}^{-1}\right)$ is less than unity, suggesting a low affinity between the adsorbate/adsorbent, and the positive value of $b_{T}\left(24.49 \mathrm{~kJ} \mathrm{~mol}^{-1}\right)$ indicates that the heat of adsorption due to interactions with adsorbate decreases linearly with the recovery rate [35], and that adsorption reaction seems to be exothermic. Furthermore the surface of activated carbon can be considered homogeneous energy. This result is related to the Langmuir observation about the homogeneity of the activated carbon surface.

4) Dubinin-Raushkevich isotherm

Dubinin and Radushkevich (D-R) proposed another isotherm used for analysis [36]. D-R hypothesis involve heterogeneity of the activated carbon surface. This isotherm equation is applied to estimate the characteristics porosity and the apparent free energy adsorption [37]. The linear form of the D-R equation is represented below:

$$
\ln Q_{e}=\ln \ln X_{m}-K_{D-R} \epsilon^{2}
$$


where, $\epsilon=R T \ln \left(1+1 / C_{e}\right), \quad Q_{e}$ is the amount adsorbed per unit mass of adsorbent $\left(\mathrm{mg} \cdot \mathrm{g}^{-1}\right), X_{m}$ is the adsorption capacity $\left(\mathrm{mg} \cdot \mathrm{g}^{-1}\right), C_{e}$ is the equilibrium concentration of BPB in solution $\left(\mathrm{mg} \cdot \mathrm{L}^{-1}\right)$, $\mathrm{R}$ the gas constant $\left(8.314 \mathrm{~J} \mathrm{~mol}^{-1} \cdot \mathrm{K}^{-1}\right)$, $K_{D-R}$ is the constant related to the adsorption energy $\left(\mathrm{mol}^{2} \cdot \mathrm{kJ}^{-2}\right)$ and $T$ is the absolute temperature $(K)$.

The plot of $\ln Q_{e}$ versus $\epsilon^{2}$ gives a straight line. The values of $X_{m}\left(0.309 \mathrm{mg} \cdot \mathrm{g}^{-1}\right)$ and $K_{D-R}\left(2.681 \mathrm{~mol}^{2} \cdot \mathrm{kJ}^{-2}\right)$ are calculated from the intercept and slope (Table 4). The porosity factor $\left(K_{D-R}\right)$ for activated carbon toward $\mathrm{BPB}$ was found to be more than unity, indicating that sorption of $\mathrm{BPB}$ on activated carbon may not be significant. That result confirms the weak adsorption capacity calculated by the Langmuir isotherm (Figure 7). From $K_{D-R}$ value, the mean energy of adsorption $E\left(\mathrm{~kJ} \cdot \mathrm{mol}^{-1}\right)$ is calculated using the following equation:

$$
E=-1 / \sqrt{2 K_{D-R}}
$$

The adsorption mechanism estimated by the magnitude of $E\left(0.43 \mathrm{~kJ} \cdot \mathrm{mol}^{-1}\right)$ is less than $16 \mathrm{~kJ} \cdot \mathrm{mol}^{-1}$ for activated carbon, which indicates that adsorption seems to be given by particle diffusion.

Since there are no other published results on BPB removal by adsorption at our knowledge, the comparison with other adsorbents is done based on the adsorption capacity of activated prepared from coconut shell (Table 5).

\subsubsection{Kinetic of Adsorption}

The kinetics of the adsorption phenomenon are determined by the mass transfer

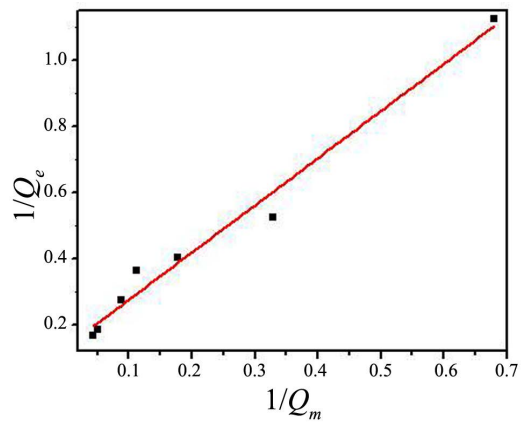

(a)

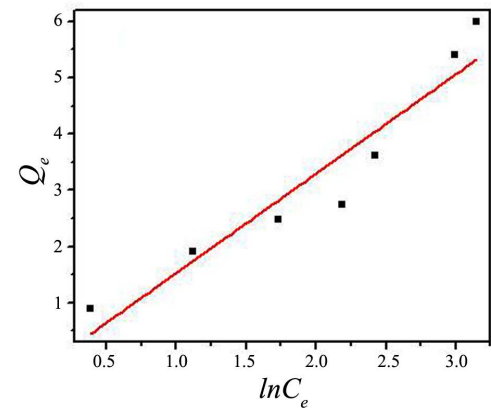

(c)

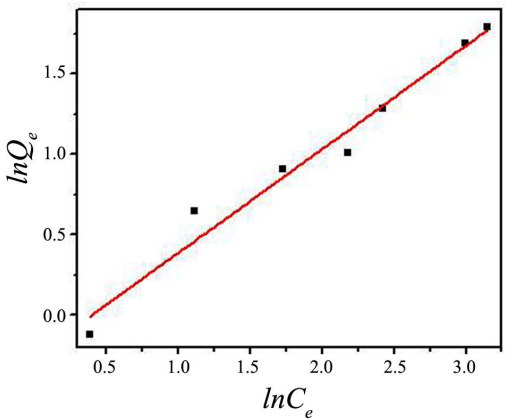

(b)

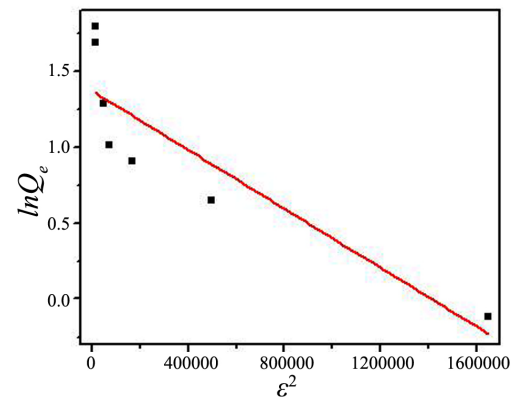

(d)

Figure 7. The Langmuir (a); Freundlich (b); Temkin (c) and Dubinin-Radushkevich (d) isotherm models for BPB adsorption using AC. 
Table 5. Comparison of adsorption capacity of activated carbon based on coconut shell.

\begin{tabular}{ccc}
\hline Pollutant & Adsorption Capacity $\left(\mathrm{mg}^{-\mathrm{g}^{-1}}\right)$ & Reference \\
\hline Reactive Blue 19 & 2.78 & {$[28]$} \\
Ammonium ions & 2.32 & {$[38]$} \\
Zn (II) & 4.28 & {$[39]$} \\
BPB & 7.52 & This study \\
\hline
\end{tabular}

to the liquid-solid interface. Adsorption kinetics modelling provides best information about the reaction pathways. The results are fitted according to different kinetics models such as the pseudo-first order equation [40], pseudo-second order equation [41] and intra-particle diffusion [35].

There are three steps in an adsorption process [42]. The first one is the external mass transfer of the adsorbate from the bulk solution to adsordent. The second one is the internal diffusion of the adsorbate to the sorption sites and the last step is the sorption itself. The pseudo-first order and the pseudo-second order are based on the fact that the sorption is the rate limiting step in the adsorption process.

1) Pseudo-first order model

The adsorption of pseudo-first order equation is established by Lagergren in $1898[40]$ and the corresponding equation is given as below:

$$
\ln \ln \left(Q_{e}-Q\right)=\ln Q_{e}-k_{1} t
$$

where $k_{1}\left(\mathrm{~min}^{-1}\right)$ is the rate constante of the adsorption, $Q$ and $Q_{e}$ are the amount adsorbed at any time and at equilibrium respectively. The plot of $\ln \left(Q_{e}-Q\right)$ versus $t$ give a straight line with correlation coefficient of 0.988 , indicating the applicability of this equation. The values of $k_{a d}$ and $Q_{e}$ are calculated from the slope and intercept. The calculated value $Q_{\text {theo }}\left(0.31 \mathrm{mg} \cdot \mathrm{g}^{-1}\right)$ found from pseudo-first order equation (Table 6) is lesser than the experimental $Q_{\text {exp }}\left(0.39 \mathrm{mg} \cdot \mathrm{g}^{-1}\right)$.

2) Pseudo-second order model

The experimental data are tested for pseudo-second order, according to Ho and McKay's [41] equation:

$$
t / Q=1 / K_{2} Q_{e}^{2}+t / Q_{e}
$$

where $k_{2}$ is the rate constant of sorption $\left(\mathrm{g} \mathrm{mg}^{-1} \cdot \mathrm{min}^{-1}\right) ; Q_{e}$ is the amount of adsorbate at equilibrium $\left(\mathrm{mg}^{-\mathrm{g}^{-1}}\right) ; Q$ is the amount of adsorbate on the surface of the adsorbent at any time $\left(\mathrm{mg} \cdot \mathrm{g}^{-1}\right)$. The plot of $t / Q$ versus $t$ gives a straight line with correlation coefficient 0.995 . The calculated adsorption capacity from the pseudo-second order equation (Table 6) is more than the experimental $Q_{\exp }$ $\left(0.39 \mathrm{mg} \cdot \mathrm{g}^{-1}\right)$.

3) Normalized standard deviation equation $(\Delta Q(\%))$

According to the correlation coefficient, the two models are close to the unity which accurately shows that the adsorption of BPB on this activated carbon follows pseudo second order. A normalized standard deviation, $\Delta Q(\%)$ is 
Table 6. Kinetic parameters for adsorption of BPB on AC by Lagergren equations.

\begin{tabular}{ccccccccc}
\hline & \multicolumn{3}{c}{ Pseudo-first-order model } & \multicolumn{4}{c}{ Pseudo-second-order model } \\
\hline$q_{e, \text { exp }}\left(\mathrm{mg} \mathrm{g}^{-1}\right)$ & $q_{e, \text { cal }}\left({\left.\mathrm{mg} \cdot \mathrm{g}^{-1}\right)} k_{1}\left(\mathrm{~min}^{-1}\right)\right.$ & $\Delta q(\%)$ & $R^{2}$ & $q_{e, \text { cal }}\left(\mathrm{mg}^{\left.-\mathrm{g}^{-1}\right)}\right.$ & $\begin{array}{c}K_{2} \\
\left(\mathrm{~g} \mathrm{mg}^{-1} \cdot \mathrm{min}^{-1}\right)\end{array}$ & $\Delta q(\%)$ & $R^{2}$ \\
0.39 & 0.31 & 0.022 & 20.4 & 0.988 & 0.43 & 0.109 & 10.2 & 0.995 \\
\hline
\end{tabular}

calculated to compare the efficiency of adsorption isotherms.

$$
\Delta Q(\%)=100 \times\left(\sum\left[\left(Q_{t}^{\exp }-Q_{t}^{c a l}\right) / Q_{t}^{\exp }\right]^{2}\right)^{1 / 2} /(n-1)
$$

where, $Q_{t}^{\exp }$ is the experimental amount adsorbed at different time $t, Q_{t}^{\text {cal }}$ is the calculated amount adsorbed at different times and $n$ is the number of observations. The $\Delta Q(\%)$ value of pseudo second order $(\Delta Q(\%)=10.2)$ is smaller than that of the pseudo first order $(\Delta Q(\%)=20.4)$, confirming that the adsorption of BPB on activated carbon follows the pseudo second order equation (Figure 8) which is in good agreement with experimental $Q_{e}$ for the activated carbon (Table 6).

4) Intra-particle diffusion model

The intra-particle diffusion model (Figure 9) was used to verify the effect of mass transfer resistance on the binding of BPB to activated carbon. This model was described by [35]:

$$
q_{t}=K_{p} t^{1 / 2}+C
$$

where, $q_{t}$ is the amount of BPB adsorbed at time $t, C$ is the resistance to the mass transfer in the film and $K_{p}$ is the intra-particle diffusion rate constant (mg $\mathrm{g}^{-1} \cdot \min ^{1 / 2}$ ).

The value of $\left(K_{p}\right), C$ and the correlation coefficient are given in Table 7. The correlation coefficient $\left(\mathrm{R}^{2}=0.943\right)$ indicates that the intra-particle transport is not the only rate of BPB adsorption onto activated carbon. This could be due to the adsorption of the solvent on the activated carbon area. Which would prevent the molecules of BPB to penetrate into the pores of activated carbon.

\subsubsection{Adsorption Thermodynamics}

The effect of temperature on the adsorption of BPB by AC is shown in Figure 10(a). The amount of BPB adsorbed decreased slightly with increasing temperature. In order to understand more deeply the adsorption process of BPB on activated carbon from coconut carbon, thermodynamic parameters such as changes in standard enthalpy $\left(\Delta H^{\circ}\right)$, stardard entropy $\left(\Delta S^{\circ}\right)$ and standard free energy $\left(\Delta G^{\circ}\right)$, were evaluated.

Thermodynamic adsorption parameters are determined from the following relationships:

$$
\begin{aligned}
\Delta G^{\circ} & =-R T \ln K_{L} \\
\Delta G^{\circ} & =\Delta H^{\circ}-T \Delta S^{\circ}
\end{aligned}
$$

where, $K_{L}$ is Langmuir constant determined from the Langmuir isotherm. 


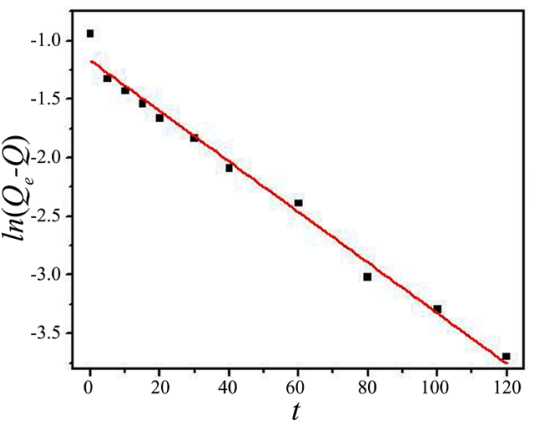

(a)

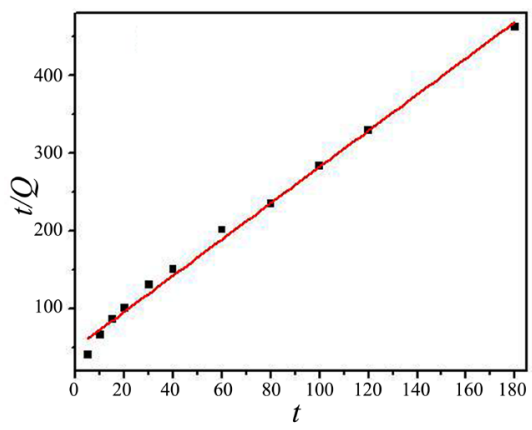

(b)

Figure 8. The pseudo-first-order (a) and pseudo-second-order (b) kinetics data of BPB adsorption on AC.

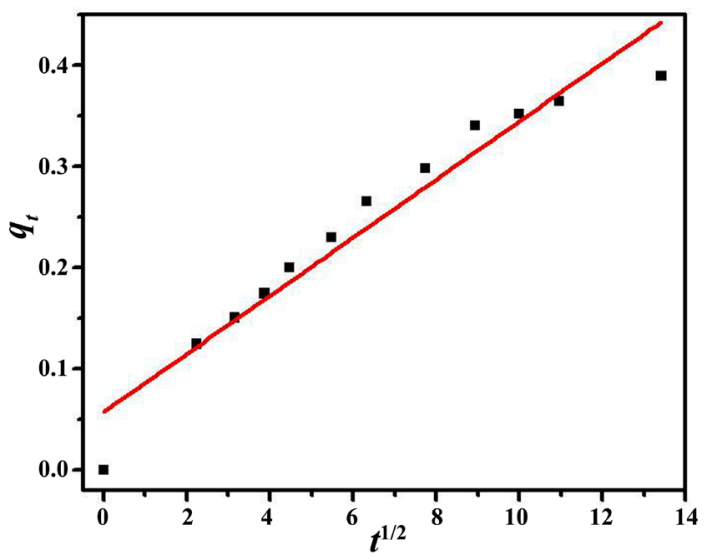

Figure 9. The intra-particle diffusion kinetics data of different BPB adsorption on AC.

Table 7. Kinetic parameters for adsorption of BPB on AC by intra-particle diffusion equation.

\begin{tabular}{ccc}
\hline & Intra-particle diffusion & \\
\hline$k_{p}\left(\mathrm{mg} \mathrm{g}^{-1} \mathrm{~min}^{-1 / 2}\right)$ & $C\left(\mathrm{mg} \mathrm{g}^{-1}\right)$ & $R^{2}$ \\
0.029 & 0.058 & 0.943 \\
\hline
\end{tabular}

The results are summarized in Table 8. The values of $\Delta H^{\circ}$ and $\Delta S^{\circ}$ can be determined from the intercept and the slope values, respectively, of the straight line of the plot of $\Delta G^{\circ}$ against $T(\mathrm{~K})$ (Figure 10(b)). The positive values of $\Delta G^{\circ}$ indicate that the adsorption of BPB on the activated carbon is not spontaneous. This result is in accordance with the intra-particle diffusion observation. The endothermic nature of the process was verified by the positive value of $\Delta H^{\circ}\left(0.0002 \mathrm{~kJ} \cdot \mathrm{mol}^{-1}\right)$. The positive value of $\Delta S^{\circ}(0.019 \mathrm{~kJ}$ $\mathrm{mol}^{-1} \cdot \mathrm{K}^{-1}$ ) explains that the degree of randomness at the solid-liquid interface increased during BPB adsorption onto the activated carbon. Similar behavior was also reported for adsorption of Reactive Blue-19 on coconut shell based activated carbon [28]. 
Table 8. Values of thermodynamic parameters for BPB removal with AC.

\begin{tabular}{cccc}
\hline Temperatures $(\mathrm{K})$ & $\Delta G^{\circ}\left(\mathrm{kJ} \mathrm{mol}^{-1}\right)$ & $\Delta H^{\circ}\left(\mathrm{kJ} \mathrm{mol}^{-1}\right)$ & $\Delta S^{\circ}\left(\mathrm{J} \mathrm{mol}^{-1} \mathrm{~K}^{-1}\right)$ \\
\hline 303 & 5.97 & 0.2 & 19 \\
323 & 6.37 & & \\
335 & 6.61 & & \\
348 & 6.86 & & \\
\hline
\end{tabular}

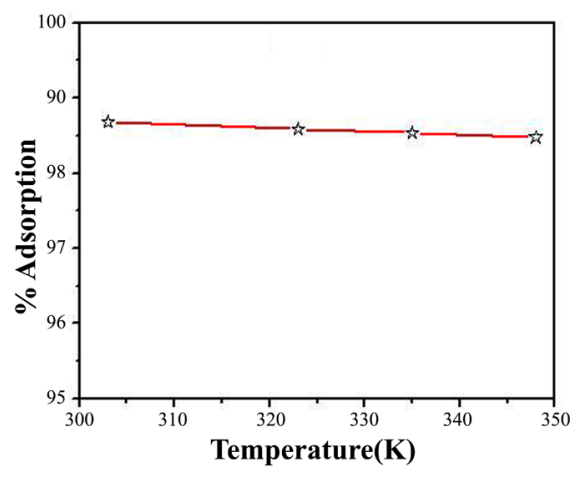

(a)

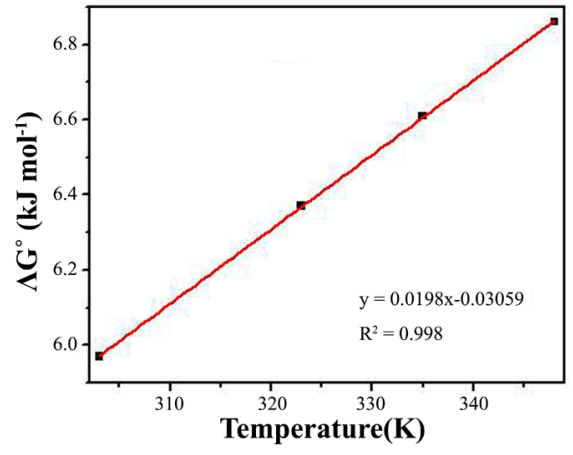

(b)

Figure 10. (a) Effect of temperature on the BPB adsorption by $\mathrm{AC}$ and (b) Plot of $\Delta G^{\circ}$ versus $T$ for the estimation of the thermodynamic parameters.

\section{Conclusions}

A cost-effective activated carbon was used as adsorbents for the removal of BPB from aqueous solution by adsorption process. The effects of some parameters (contact time, temperature, $\mathrm{pH}$, and ionic strength) on adsorption were evaluated. The adsorption increased with increasing adsobent dose, while it was decreasing with increasing $\mathrm{pH}$, temperature and ionic strength. The experimental adsorption capacities of the $\mathrm{AC}$ for the adsorption of $\mathrm{BPB}$ determined as $98 \%$ in acidic media. The Langmuir adsorption capacity of the BPB was found to be $7.52 \mathrm{mg} \cdot \mathrm{g}^{-1}$. The adsorption was in consistent with the Langmuir, Freundlich and Temkin isotherm models and with the pseudo-second order kinetic model. The adsorption was of non-spontaneous and endothermic nature. The CBAC could be also used for the process design and it could be used as a potential adsorbent for the removal of various compounds from wastewaters.

The coconut shells used in this present work are considered as waste and abundantly available with promises affordable adsorbent for the removal of BPB from aqueous solution that is suitable for the wastewater treatment.

\section{Conflict of interest}

The authors declare no competing financial interest.

\section{Acknowledgements}

This study was financially supported by The National Sciences and Engineering 
Research Council of Canada. Authors thank Dr. Nicolas Keller at Institut de Chimie et Procedés Pour l'Energie, l'Environnement et la Santé (ICPEES), CNRS University of Strasbourg, France, for his support. Author N.B.A. acknowledges CSIR-India and TWAS-Italy for award of the CSIR-TWAS fellowship (FR number: 3240280453) for postgraduate studies at CSIR-NEIST, Jorhat, India.

\section{References}

[1] World Health Organization. (2002) Global Assessment of The State-of-the-Science of Endocrine Disruptors.

[2] Golden, R., Gandy, J. and Vollmer, G. (2005) A Review of the Endocrine Activity of Parabens and Implications for Potential Risk to Human Health. Critical Reviews in Toxicology, 35, 435-458. https://doi.org/10.1080/10408440490920104

[3] Gryglik, D., Lach, M. and Miller, J.S. (2009) The Aqueous Photosensitized Degradation of Butylparaben. Photochemical \& Photobiological Science, 8, 549-555. https://doi.org/10.1039/b817846a

[4] Bledzska, D., Gryglik, D. and Miller, J.S. (2009) Photodegradation of Butylparaben in Aqueous Solutions by $254 \mathrm{~nm}$ Irradiation. Journal of Photochemistry and Photobiology A: Chemistry, 203, 131-136. https://doi.org/10.1016/j.jphotochem.2009.01.006

[5] Tay, K.S., Rahman, N.A. and Abas, M.R.B. (2010) Kinetic Studies of the Degradation of Parabens in Aqueous Solution by Ozone Oxidation. Environmental Chemistry Letters, 8, 331-337. https://doi.org/10.1007/s10311-009-0229-7

[6] Radovan, C., Cinghita, D., Manea, F., Mincea, M., Cofan, C. and Ostafe, V. (2008) Electrochemical Sensing and Assessment of Parabens in Hydro-Alcoholic Solutions and Water Using a Boron-Doped Diamond Electrode. Sensor, 8, 4330-4349. https://doi.org/10.3390/s8074330

[7] Terasaki, M., Takemura, Y. and Makino, M. (2012) Paraben Chlorinated Derivatives in River Waters. Environmental Chemistry Letters, 10, 401-406. https://doi.org/10.1007/s10311-012-0367-1

[8] Terasaka, S., Inoue, A., Tanji, M. and Kiyama, R. (2006) Expression Profiling of Estrogen-Responsive Genes in Breast Cancer Cells Treated with Alkylphenols, Chlorinated Phenols, Parabens, or Bis- and Benzoylphenols for Evaluation of Estrogenic Activity. Toxicology Letters, 163, 130-141. https://doi.org/10.1016/j.toxlet.2005.10.005

[9] Tavares, R.S., Martins, F.C., Oliveira, P.J., Ramalho-Santos, J. and Peixoto, F.P. (2009) Paraben in Male Infertility Is There a Mitochondrial Connection? Reproductive Toxicology, 27, 1-7. https://doi.org/10.1016/j.reprotox.2008.10.002

[10] Gomez, M.J., Sirtori, C., Mezcua, M., Fernandez-Alba, A.R. and Aguera, A. (2008) Photodegradation Study of Three Dipyrone Metabolites in Various Water Systems: Identification and Toxicity of Their Photodegradation Products. Water Research, 42, 2698-2706. https://doi.org/10.1016/j.watres.2008.01.022

[11] Atheba, P., Drogui, P., Seyhi, B. and Robert, D. (2013) Photo-Degradation of Butyl Parahydroxybenzoate by Using $\mathrm{TiO}_{2}$-Supported Catalyst. Water Science and Technology, 67, 2141-2147. https://doi.org/10.2166/wst.2013.117

[12] Boutemedjet, S., Hamdaoui, O., Merouani, S. and Pétrier, C. (2016) Sonochemical Degradation of Endocrine Disruptor Propylparaben in Pure Water, Natural Water, and Seawater. Desalination and Water Treatment, 57, 27816-27826.

https://doi.org/10.1080/19443994.2016.1177600 
[13] Daghrir, R., Diboukou-Mpira, A., Seyhi, B. and Drogui, P. (2014) Photosonochemical Degradation of Butyl-Paraben: Optimization, Toxicity and Kinetic Studies. Science of The Total Environment, 490, 223-234. https://doi.org/10.1016/j.scitotenv.2014.05.006

[14] Atheba, G.P., Allou, N.B., Dongui, B.K., Kra, D.O., Gbassi, K.G. and Trokourey, A. (2015) Butyl Paraben Adsorption on Coal Based on Low Cost of Coconut Shells from Côte d'Ivoire. International Journal of Innovation and Scientific Research, 13, 530-541.

[15] Lee, H.B., Peart, T.E. and Svoboda, M.L. (2005) Determination of Endocrine-Disrupting Phenols, Acidic Pharmaceuticals, and Personal-Care Products in Sewage by Solid-Phase Extraction and Gas Chromatography-Mass Spectrometry. Journal of Chromatography A, 1094, 122-129. https://doi.org/10.1016/j.chroma.2005.07.070

[16] Radjenovic, J., Bagastyo, A., Batstone, D. and Keller, J. (2014) Electrochemical Treatment of Reverse Osmosis Concentrates. Encyclopedia of Applied Electrochemistry, 644-651. https://doi.org/10.1007/978-1-4419-6996-5_136

[17] Senthilkumar, T., Chattopadhyay, S.K. and Miranda, L.R. (2017) Optimization of Activated Carbon Preparation from Pomegranate Peel (Punica Granatum Peel) using RSM. Chemical Engineering Communications, 204, 238-248. https://doi.org/10.1080/00986445.2016.1262358

[18] Koçer, O. and Acemioğlu, B. (2016) Adsorption of Basic Green 4 from Aqueous Solution by Olive Pomace and Commercial Activated Carbon: Process Design, Isotherm, Kinetic and Thermodynamic Studies. Desalination and Water Treatment, 57, 16653-16669. https://doi.org/10.1080/19443994.2015.1080194

[19] Atheba, P., Gbassi, G.K., Dongui, B., Bamba, D., Yolou, F.S. and Trokourey, A. (2014) Études de la Porosité, de la Surface Spécifique et des Fonctions de Surface de Charbons Actifs Préparés après Carbonisation Artisanale des Coques de Noix de Coco. Technologies de Laboratoire, 8, 126-136.

[20] Atheba, G.P. (2009) Traitement des Eaux par Action Combinée de la Photocatalyse et de l'Adsorption sur Charbon Actif: Conception et Réalisation du Procédé. Thèse de doctorat, Université Paul Verlaine, Metz.

[21] Salame, I.I., Bagreev, A. and Bandosz, T.J. (1999) Revisiting the Effect of Surface Chemistry on Adsorption of Water on Activated Carbons. Journal Physical Chemistry $B, 103,3877-3884$. https://doi.org/10.1021/jp984453q

[22] Zue, M.M., Makani, T. and Eba, F. (2016) Removal of Mn (II) from Aqueous Solutions by Activated Carbons Prepared from Coula Edulis Nut Shell. Journal of Environmental Science and Technology, 9, 226-237. https://doi.org/10.3923/jest.2016.226.237

[23] Chen, S., Zhang, J., Zhang, C., Yue, Q., Li, Y. and Li, C. (2010) Equilibrium and Kinetic Studies of Methyl Orange and Methyl Violet Adsorption on Activated Carbon Derived from Phragmites australis. Desalination, 252, 149-156. https://doi.org/10.1016/j.desal.2009.10.010

[24] Seyhi, B., Drogui, P., Gortares-Moroyoqui, P., Estrada-Alvarado, M.I. and Alvarez, L.H. (2014) Adsorption of an Organochlorine Pesticide Using Activated Carbon Produced from an Agro-Waste Material. Journal of Chemical Technology Biotechnology, 89, 1811-1816. https://doi.org/10.1002/jctb.4256

[25] Kra, D.O., Kouadio, N.A., Atheba, G.P., Coulibaly, B., Allou, N.B., Gbassi, K.G. and Trokourey, A. (2015) Modeling of the Adsorbent Properties of Activated Carbons Resulting from Two Varieties of Acacia (Auriculiformis and Mangium). International Journal of Innovation and Scientific Research, 13, 542-553. 
[26] Aboua, K.N., Yeboue, Y.A., Yao, K.B., Goné, D.L. and Trokourey, A. (2015) Investigation of Dye Adsorption onto Activated Carbon from the Shells of Macoré Fruit. Journal of Environment Management, 156, 10-14. https://doi.org/10.1016/j.jenvman.2015.03.006

[27] Heibati, B., Rodriguez-Couto S., Amrane, A., Rafatullah, M., Hawari, A. and Al Ghouti, M.A. (2014) Uptake of Reactive Black 5 by Pumice and Walnut Activated Carbon: Chemistry and Adsorption Mechanisms. Journal of Industrial and Engineering Chemistry, 20, 2939-2947. https://doi.org/10.1016/j.jiec.2013.10.063

[28] Isah, U.A., Abdulraheem, G., Bala, S., Muhammad, S. and Abdullahi, M. (2015) Kinetics, Equilibrium and Thermodynamics Studies ff C.I. Reactive Blue 19 Dye Adsorption on Coconut Shell Based Activated Carbon. International Biodeterioration \& Biodegradation, 102, 265-273. https://doi.org/10.1016/j.ibiod.2015.04.006

[29] Hawari, A., Rawajfih, Z. and Nsour, N. (2009) Equilibrium and Thermodynamic Analysis of Zinc Ions Adsorption by Olive Oil Mill Solid Residues. Journal of Hazardous Materials, 168, 1284-1289. https://doi.org/10.1016/j.jhazmat.2009.03.014

[30] Jawad, A.H., Rashid, R.A., Ishak, M.A.M. and Wilson, L.D. (2016) Adsorption of Methylene Blue onto Activated Carbon Developed from Biomass Waste by $\mathrm{H}_{2} \mathrm{SO}_{4}$ Activation: Kinetic, Equilibrium and Thermodynamic Studies. Desalination and Water Treatment, 57, 25194-25206. https://doi.org/10.1080/19443994.2016.1144534

[31] Bhatnagar, A. and Jain, A.K. (2005) A Comparative Adsorption Study with Different Industrial Wastes as Adsorbents for the Removal of Cationic Dyes from Water. Journal of Colloid and Interface Science, 281, 49-55. https://doi.org/10.1016/j.jcis.2004.08.076

[32] Azmi, N.H., Ali, U.F.Md., Ridwan, F.M., Isa, K.Md., Zulkurnai, N.Z. and Aroua, M.K. (2016) Preparation of Activated Carbon Using Sea Mango (Cerbera odollam) with Microwave Assisted Technique for the Removal of Methyl Orange from Textile Wastewater. Desalination and Water Treatment, 57, 29143-29152. https://doi.org/10.1080/19443994.2016.1168134

[33] Timbo, C.C., Kandawa-Schulz, M., Amuanyena, M. and Kwaambwa, H.M. (2017) Adsorptive Removal from Aqueous Solution of $\mathrm{Cr}(\mathrm{VI})$ by Green Moringa Tea Leaves Biomass. Journal of Encapsulation and Adsorption Sciences, 7, 108-119. https://doi.org/10.4236/jeas.2017.72008

[34] Djilani, C., Zaghdoudi, R., Djazi, F., Bouchekima, B., Lallam, A., Modarressi, A. and Rogalski, M. (2015) Adsorption of Dyes on Activated Carbon Prepared from Apricot Stones and Commercial Activated Carbon. Journal of Taiwan Institute of Chemical Engineering, 53, 112-121. https://doi.org/10.1016/j.jtice.2015.02.025

[35] Allou, N.B., Saikia, J. and Goswamee, R.L. (2018) Use of Calcined Mg-Al Layered Double Hydroxides to Regulate Endocrine Disruptor Methylparaben in Excess as Adsorbent and as Control Releasing Agent in Normal Situations. Journal of Environmental Chemical Engineering, 6, 1189-1200.

https://doi.org/10.1016/j.jece.2017.12.015

[36] N'guyen, C. and Do, D.D. (2001) The Dubinin-Radushkevich Equation and the Underlying Microscopic Adsorption Description. Carbon, 39, 1327-1336. https://doi.org/10.1016/S0008-6223(00)00265-7

[37] Horsfall Jnr, M. and Spiff, A.I. (2005) Effect of Metal Ion Concentration on the Biosorption of $\mathrm{Pb}^{2+}$ and $\mathrm{Cd}^{2+}$ by Caladium Bicolor (Wild Cocoyam). African Journal of Biotechnology, 4, 191-196.

[38] Boopathy, R., Karthikeyan, S., Mandal, A.B. and Sekaran, G. (2013) Adsorption of Ammonium Ion by Coconut Shell-Activated Carbon from Aqueous Solution: Ki- 
netic, Isotherm, and Thermodynamic Studies. Environmental Science and Pollution Research, 20, 533-542. https://doi.org/10.1007/s11356-012-0911-3

[39] Behnamfard, A. and Salarirad, M.M. (2013) Characterization of Coconut Shell-Based Activated Carbon and its Application in the Removal of $\mathrm{Zn}$ (II) from Its Aqueous Solution by Adsorption. Desalination and Water Treatment, 52, 7180-7195.

[40] Chraibi, S., Moussout, H., Boukhlifi, F., Ahlafi, H. and Alami, M. (2016) Utilization of Calcined Eggshell Waste as an Adsorbent for the Removal of Phenol from Aqueous Solution. Journal of Encapsulation and Adsorption Sciences, 6, 132-146. https://doi.org/10.4236/jeas.2016.64010

[41] Nethaji, S., Sivasamy, A. and Mandal, A.B. (2013) Preparation and Characterization of Corn Cob Activated Carbon Coated with Nano-Sized Magnetite Particles for the Removal of Cr (VI). Bioresource Technology, 134, 94-100.

https://doi.org/10.1016/j.biortech.2013.02.012

[42] Largitte, L. and Laminie, J. (2015) Modelling the Lead Concentration Decay in the Adsorption of Lead onto a Granular Activated Carbon. Journal of Environmental Chemical Engineering, 3, 474-481. https://doi.org/10.1016/j.jece.2014.12.020 